\title{
Pelanggaran UU ITE pada Media Sosial dalam Etika Komunikasi Massa
}

${ }^{1}$ Selviana Teras Widy Rahayu, ${ }^{2}$ Ruisah

${ }^{1}$ Universitas Pamulang, Tangerang Selatan, Indonesia

2 Universitas Pamulang, Tangerang Selatan, Indonesia

Email:

dosen02107@unpam.ac.id

dosen00300@unpam.ac.id

\section{Article Information}

Submmited Juni, 2022

Revision Juni, 2022

Accepted Juni, , 2022

Published Juni , 2022

Keywords

etika, komunikasi Massa,

media sosial, UU ITE

\begin{abstract}
ABSTRAKS
Sosialisasi UU ITE terus dijalankan dan belajar mengenal indikasi pelanggarannya. Etika komunikasi massa seperti apa yang belum diterapkan pada media sosial? Artikel ini bertujuan untuk menganalisis indikasi hambatan atau pelanggaran UU ITE dalam etika komunikasi massa. Penelitian ini menggunakan pendekatan kualitatif dengan paradigma konstruktivis. Tiga teks dari sumber teks di media digital. Ditemukan tiga pelanggaran UU ITE pasal 28: 1)tampilan grafik dan penyalahgunaan makna grafik, 2) struktur Bahasa membingungkan, dan 3) salah persepsi karena latarbelakang budaya.
\end{abstract}

\section{Pendahuluan}

Penyalahgunaan media sosial termasuk pelanggaran etika, pelanggaran nilai moral, norma-norma, dan lainnya pun terjadi sebagai bagian dari proses komunikasi di era digital ini. Pelanggaran UU ITE dan pelanggaran etika komunikasi massa disebarnya berita bohong dan berita palsu. Pelanggaran-pelanggaran tersebut sering terjadi karena pesatnya perkembangan teknologi yang memudahkan seseorang untuk berkomunikasi dalam waktu yang lebih singkat dan banyak pengguna teknologi yang tidak berhati-hati dalam mengumpulkan informasi, sehingga terjebak dalam berita palsu yang disebarkan oleh pelaku penyebar berita palsu.

Salah satu kasus yang belakangan ini sering dijumpai dan juga ditemukan wilayah yang lebih luas adalah berita-berita dengan hal-hal yang bersifat penyebaran kebencian, terutama dalam kehidupan beragama di media sosial. Penyebaran informasi kebencian, provokatif pada dasarnya hanyalah opini. Penyebaran disinformasi ini merupakan pelanggaran etika media sosial yang tercantum dalam Pasal 28 ayat 2 UU ITE Nomor 11 Tahun 2008 tentang informasi dan transaksi elektronik yang berbunyi “ Setiap orang dengan sengaja dan tanpa hak menyebarkan informasi yang ditujukan untuk menimbulkan rasa kebencian atau permusuhan individu dan/atau kelompok masyarakat tertentu berdasarkan atas suku, agama, ras, dan antargolongan (SARA)".

Masyarakat wajib memahami pentingnya etika komunikasi massa melalui praktik komunikasi berbasis jaringan atau jejaring sosial. Tentu saja, jika komunikasi massa tidak etis, hal tersebut dapat membingungkan dan kerugian besar bagi masyarakat sendiri. Oleh karena itu, media sosial sebaiknya digunakan sebagai sarana komunikasi yang sehat dan terkendali dengan menerapkan etika komunikasi yang baik. Masyarakat harus cerdas memahami konsep dalam komunikasi. 
Menurut Ross dalam Ilmu Komunikasi, komunikasi adalah proses memilah, memilih dan mengirimkan simbol. Simbol sedemikian rupa sehingga membantu pendengar membangkitkan makna atau tanggapan dari pikirannya yang serupa dengan yang dimaksudkan oleh komunikator. Intinya, yang disampaikan Ross adalah adanya respon balik dari pesan yang disampaikan oleh komunikator agar sama dengan apa yang dimaksud oleh komunikator (Mulyana 2007).

Menurut Rogers dan Kincaid pada tahun 1981 dalam Pengantar Ilmu Komunikasi Cangara, komunikasi adalah suatu proses di mana dua orang atau lebih membentuk atau bertukar informasi satu sama lain, yang pada gilirannya akan sampai pada saling pengertian yang mendalam (Cangara, 2006).

Perubahan atau penguatan keyakinan terhadap pengetahuan, tindakan, dan sikap seseorang sebagai akibat dari menerima pesan. Umpan balik adalah keluaran yang dihasilkan berupa respon atau tanggapan berupa hasil pengaruh pesan (pesan yang disampaikan oleh komunikator kepada komunikan). Antara komunikator dan komunikan dalam jaringan komunikasi, komunikator ingin mendapatkan umpan balik yang positif, negatif, atau netral (Cangara, 2006).

Media sosial merupakan salah satu produk dari munculnya media baru. Di media sosial, individu dan kelompok berinteraksi satu sama lain secara online melalui jaringan internet. Sejak kemunculannya, media sosial tidak hanya digunakan oleh individu tetapi juga oleh organisasi atau perusahaan besar dan kecil untuk berkomunikasi dengan publik.

Jika dikaitkan dengan aktivitas eksistensi diri di dunia maya, dalam hal ini jejaring sosial, orang dapat mengomunikasikan aktivitas apa pun yang mereka lakukan sepanjang hari, karena di media sosial siapa pun dapat mengekspresikan ide-idenya dalam bentuk tulisan maupun visual. Lebih lanjut Dave Evan dalam bukunya yang berjudul Social Media Marketing One Hour a Day menjelaskan bahwa media sosial telah mendemokrasikan informasi, mengubah orang dari pembaca konten menjadi penerbit konten. Ini adalah pergeseran dari mekanisme siaran ke model banyak-ke-banyak, berakar pada percakapan antara penulis, orang-orang dan rekanrekan. Media sosial menggunakan "konsep orang" untuk terhubung dengan informasi bersama (Evans \& Bratton, 2012).

Undang-Undang Informasi dan Transaksi Elektronik adalah undang-undang yang mengatur tentang Informasi Elektronik dan Transaksi Elektronik. Pengertian Informasi Elektronik adalah satu atau sekumpulan data elektronik, termasuk namun tidak terbatas pada tulisan, suara, gambar, peta, rancangan, foto, electronic data interchange (EDI), surat elektronik, telegram, teleks, telecopy atau sejenisnya, surat, tanda, angka, Olahan Kode Akses, simbol atau perforasi yang memiliki arti atau dapat dipahami oleh orang yang mampu memahaminya. Sedangkan Transaksi Elektronik adalah perbuatan hukum yang dilakukan dengan menggunakan komputer, jaringan komputer, dan/atau media elektronik lainnya. Berdasarkan permasalahan di atas terdapat dua tujuan penelitian yaitu, mengetahui bentuk pelanggaran etika komunikasi massa dalam media sosial menurut UU ITE dan mengetahui penegakan hukum terhadap pelanggaran etika komunikasi dalam media sosial menurut UU ITE.

\section{Metode Penelitian}

Penelitian ini menggunakan metode kualitatif, yaitu mengembangkan dan menggunakan diperlukan teknik analisis yuridis deskriptif, yaitu dengan menyelaraskan dan menggambarkan keadaan yang sebenarnya kemudian berdasarkan hasil wawancara dan studi pustaka yang telah dilakukan. diperoleh, data tersebut akan diolah dan dianalisis secara kualitatif sehingga dapat menghasilkan data deskriptif. Dari analisis data dilanjutkan dengan penarikan kesimpulan dari metode induktif yaitu cara berpikir khusus kemudian ditarik kesimpulan umum untuk menjawab permasalahan yang diajukan.

\section{Landasan Teori}




\section{Hambatan Komunikasi Massa}

. Pengkajian komunikasi Massa banyak dipengaruhi oleh dinamika media Massa dan penggunaannya oleh khalayak. Perkembangan media Massa sendiri banyak dikaitkan dengan sejumlah faktor yang melingkupinya, misalnya jumlah melek huruf yang semakin besar, perkembangan pesat dalam bidang ekonomi, kemajuan teknologi informasi dan komunikasi, fenomena urbanisasi, dan faktor iklan (Halik, 2013).

Menurut Bittner (1980), komunikasi Massa merujuk pada proses komunikasi di mana pesan-pesan yang disampaikan melalui media Massa pada sejumlah besar orang. Media Massa adalah sarana utama dalam komunikasi Massa untuk menyebarkan pesan- pesan kepada khalayak. Media Massa dapat berupa media Massa cetak seperti surat kabar, majalah, dan buku; media elektronik seperti radio dan televisi; serta media digital (internet). Karakteristik utama komunikasi Massa lainnya adalah jumlah khalayaknya yang sangat besar (Junaedi, 2019).

DeFleur dan Dennis (1985) mengartikan komunikasi massa sebagai proses komunikasi yang ditandai oleh penggunaan media bagi komunikatornya untuk menyebarkan pesan-pesan secara luas, dan terus-menerus diciptakan makna-makna yang diharapkan dapat mempengaruhi khalayak yang besar dan berbeda-beda melalui berbagai cara. Sementara Ruben (1992), mendefinisikan komunikasi Massa sebagai suatu proses di mana informasi diciptakan dan disebarkan oleh organisasi untuk dikonsumsi khalayak.

Berikut ini adalah dua hal yang merupakan hambatan komunikasi yang harus menjadi perhatian bagi komunikator jika ingin komunikasinya sukses. Hambatan dalam komunikasi dapat dibedakan atas hambatan psikologis, hambatan sosio-kultural, hambatan mekanis, dan hambatan interaksi verbal.

a) Hambatan psikologis. Berkenaan dengan unsur psikis manusia, berupa: a. Kepentingan (interest) yang berkaitan dengan sikap selektif dalam menanggapi dan menghayati pesan. Kepentingan komunikan mempengaruhi perhatian terhadap stimulus, daya tanggap, perasaan, pikiran, tingkah laku, sikap reaktif terhadap pesan. Kepentingan komunikan didasarkan pada manfaat atau kegunaan pesan baginya. Komunikan akan melakukan proses seleksi sajian media yang menarik baginya dan sesuai kepentingannya. Sementara komunikan dalam komunikasi Massa adalah sejumlah besar khalayak yang tersebar luas. Mereka memiliki minat dan perhatian yang sangat beragam dan unik. Pesan-pesan komunikasi yang bersifat umum berkonsekuensi pada perbedaan tingkat perhatian dan ketertarikan khalayak atas pesan-pesan tersebut. Terdapatnya gejala segmentasi khalayak merupakan pertimbangan tersendiri bagi para produsen informasi dalam komunikasi Massa. Dimensi isi media komunikasi yang diproduksi dituntut agar memiliki daya tarik yang kuat, agar program atau materi yang ditawarkan mendapat perhatian dari semua golongan audien, termasuk kelompok yang tidak termasuk sasaran utamanya. b. Prasangka (prejudice) adalah persepsi orang tentang seseorang atau kelompok lain dan sikap perilakunya. Persepsi merupakan pengalaman tentang objek, peristiwa, atau hubunganhubungan yang diperoleh dengan menyimpulkan informasi dan menafsirkan pesan. Persepsi ditentukan oleh faktor personal (fungsional) dan situasional. Faktor personal berkaitan dengan kebutuhan, pengalaman masa lalu, peran, dan status. Persepsi ditentukan karakteristik yang memberi respon pada stimuli, bukan jenis atau bentuk stimuli. Sementara faktor situasional (struktural) berkaitan dengan sifat stimuli secara fisik. Umumnya prasangka suatu kelompok masyarakat tertentu terhadap kelompok masyarakat lainnya karena perbedaan suku, ras, dan agama. Prasangka dalam komunikasi terjadi saat komunikan menentang (pribadi) komunikator. Prasangka lebih bersifat emosional daripada rasional,subjektif, dan cenderung menunjukkan penilaian negatif. Ditambah melakukan pukul rata atau stereotip negatif.

b) Hambatan sosio-kultural. Perbedaan budaya mengakibatkan perbedaan norma-norma sosial. Sementara cara, kebiasaan, tata kelakuan, adat istiadat yang disampaikan turun-temurun, dapat memberi petunjuk bagi seseorang untuk bersikap dan bertingkah laku dalam masyarakat. Hambatan sosio- kultural dapat dibedakan atas hambatan faktor-faktor norma sosial dan hambatan semantik. 
c). Hambatan mekanik adalah gangguan yang disebabkan saluran komunikasi atau kegaduhan yang bersifat fisik (suara kresek-kresek radio, gambar tidak jelas di televisi, halaman surat kabar yang terobek, bunyi kendaraan lewat waktu berpidato, dsb). Sedangkan gangguan semantik adalah gangguan yang berkaitan dengan pesan/isi komunikasi dan ini berhubungan dengan salah pengertian sebagai akibat dari lambang-lambang yang digunakan dalam berkomunikasi difahami berbeda oleh masing-masing peserta komunikasi.

d). Hambatan interaksi verbal tersebut dapat terjadi karena beberapa macam faktor. Di antaranya : stereotip, labbeling, polarisasi, kurang objektif dan bias informasi.

Untuk mengetahui apa itu etika komunikasi Massa, ada baiknya kita pahami kembali arti etika yang telah dikemukakan oleh para ahli. Beberapa diantaranya adalah sebagai berikut:

a. Menurut H Altschull (1990), etika merupakan sebuah studi berbagai bentuk nilainilai moral dan prinsip-prinsip benar atau salah;

b. Menurut Donald K. Wright (2010), etika adalah cabang dari filsafat yang berkaitan dengan perilaku moral atau seperangkat prinsip-prinsip atau kode etik moral. (Baca juga : Filsafat Komunikasi - Ontologi, Epistemologi, dan Aksiologi);

c. Menurut Dictionary of Media, etika adalah berbagai aturan atau prinsip perilaku yang ditujukan sebagai pedoman tindakan;

d. Menurut Dictionary of Mass Communication and Media Research (2005), etika merupakan seperangkat peraturan atau prinsip-prinsip untuk memandu perilaku. Etika atau filsafat moral juga dapat diartikan sebagai sebuah disiplin yang menekankan pada apa yang baik dan apa yang buruk, apa yang benar dan apa yang salah. Sedangkan, yang dimaksud dengan moralitas adalah derajat kebenaran atau kesalahan dari sebuah tindakan.

Penggunaan istilah etika dan moralitas dalam komunikasi Massa utamanya menekankan etika sebagai seperangkat prinsip-prinsip dan bukan sebagai disiplin ilmu. Dengan potensi pesan komunikasi Massa yang dapat mencapai khalayak yang sangat luas, maka potensi pesan dalam komunikasi Massa berkonsekuensi positif atau negatif melebihi pesan komunikasi interpersonal atau komunikasi antar pribadi, komunikasi kelompok, atau komunikasi publik. Oleh karena itu, saat membahas komunikasi Massa dan media, kita harus memperhatikan segala sesuatu yang terkait erat dengan etika. Komunikasi melalui media Massa yang etis merupakan hal yang paling mendasar bagi pemikiran yang bertanggung jawab, pengambilan keputusan, dan pengembangan hubungan dengan masyarakat di dalam konteks maupun antar konteks baik budaya, media atau saluran komunikasi, dan media. Dengan demikian, yang dimaksud dengan etika komunikasi Massa adalah seperangkat moral yang menjadi pedoman bagi para praktisi komunikasi Massa dalam menjalankan tugas dan kewajiban profesionalnya. Etika memaksa para profesional untuk menyadari prinsip-prinsip dasar dan nilai-nilai, serta kewajibannya terhadap diri mereka sendiri dan orang lain. Etika memaksa para profesional untuk memutuskan bagaimana untuk hidup, bagaimana untuk mengawal hubungan antara dirinya dan orang lain, bagaimana ia berpikir, bertindak, dan beraksi terhadap orang-orang serta berbagai isu yang ada di sekitar mereka (Junaedi, 2019).

Etika komunikasi Massa terkait dengan peraturan kepemilikan media, media dan globalisasi, dan representasi keragaman. Etika komunikasi Massa mencakup beberapa bidang, di antaranya adalah etika jurnalistik serta etika media. Media Massa diatur dengan hukum dan sebuah sistem etika. Tanpa adanya hukum dan etika maka media Massa dapat disalahgunakan atau dimanfaatkan oleh pihak-pihak yang tidak bertanggung jawab dan memiliki kepentingan tertentu. Yang dimaksud dengan etika media adalah cabang filsafat yang membantu para profesional media untuk memiliki standar moral. Sementara etika komunikasi Massa dapat memberikan berbagai manfaat, diantaranya adalah :

a. Memahami pengertian etika;

b. Memahami pengertian etika komunikasi massa; 
c. Memahami cakupan etika komunikasi massa.

d. Memahami kaitan antara pengambilan keputusan dan etika komunikasi massa;

e. Memahami kaitan antara dilema dalam etika komunikasi massa.

\section{Undang-Undang ITE}

Melalui media internet, setiap individu dapat melakukan berbagai aktifitas yang lebih mudah akan tetapi kemudahan tersebut dibatasi oleh negara dengan cara memberlakukan UU No. 19 Tahun 2018 tentang perubahan UU No. 11 Tahun 2008 tentang Informasi dan Transaksi Elektronik (UU ITE). Dengan adanya Undang-undang tersebut sudah sepatutnya masyarakat memahami hal apa saja yang tidak boleh ditulis dan dibagikan melalui media sosial. Oleh karena itu, hukum tidak hanya sekedar dipahami sebagai norma yang menjamin kepastian dan keadilan tetapi juga harus dilihat dari perspektif kemanfaatannya (Rawl, 2006: 513). Adapun UU No. 19 Tahun 2016 ini sifatnya bukan untuk melarang orang berpendapat maupun mengkritisi di media sosial. Perlu dipahami bahwa Pasal 28E ayat (3) secara tegas menyatakan bahwa "Setiap orang berhak atas kebebasan berserikat, berkumpul dan mengeluarkan pendapat". Sehingga dengan demikian diketahui pula bahwa kebebasan di media sosial adalah kebebasan yang merupakan Hak Asasi Manusia (HAM) yang dilindungi oleh konstitusi. Namun demikian perlu dilihat pula Pasal 28J ayat (2) UUD NRI Tahun 1945, karena dalam pasal tesebut dinyatakan pula bahwa "Dalam menjalankan hak dan kebebasannya, setiap orang wajib tunduk kepada pembatasan yang ditetapkan dengan undang-undang dengan maksud semata-mata untuk menjamin pengakuan serta penghormatan atas hak dan kebebasan orang lain dan untuk memenuhi tuntutan yang adil sesuai dengan pertimbangan moral, nilai-nilai agama, keamanan, dan ketertiban umum dalam suatu masyarakat demokratis." Oleh karena itu, HAM bukanlah kebebasan yang tanpa batasan melainkan negara perlu mengatur batasan-batasannya karena HAM seseorang dibatasi pula oleh HAM orang lain sesuai dengan amanat Pasal 28J ayat (2) UUD NRI Tahun 1945 tersebut. Pasal 1 ayat (3) UUD NRI Tahun 1945 menegaskan bahwa "Negara Indonesia adalah negara hukum". Lebih lanjut lagi, sistem hukum yang dianut oleh negara kita adalah civil law. Titik tekan pada sistem hukum ini adalah, penggunaan aturan-aturan hukum yang sifatnya tertulis. Oleh karena itu, dalam rangka membangun etika bagi pengguna media melalui pembentukan UU No. 19 Tahun 2016 adalah langkah yang tepat. Dalam negara hukum segala sesuautu harus dilakukan menurut hukum (everything must be done according to law) (Sugiarso et al., 2017).

\section{DISKUSI}

\section{Pelanggaran Etika Komunikasi Massa}

Komunikasi adalah jenis proses sosial yang erat kaitannya dengan aktivitas manusia serta sarat akan pesan maupun perilaku. Melalui komunikasi, seseorang dapat menyampaikan sebuah berita, saling bertukar informasi, mengajukan sebuah gagasan atau ide, maupun bersosialisasi dengan orang lain. Komunikasi tidak hanya dilakukan secara tatap muka, namun saat ini sudah dapat dilakukan melalui media digital atau online. Komunikasi dapat dilakukan melalui perantara kata-kata dan kalimat, lambang, tanda, maupun tingkah laku. Komunikasi ini sendiri pun dapat dituangkan dalam berbagai bentuk media, seperti kata-kata, gambar, angka, tulisan, dan bahkan video.

Etika yang diabaikan dalam dunia komunikasi dapat menghilangkan kepekaan sosial dan rasa peduli terhadap sesama. Komunikasi memang sangat diperlukan di dalam bersosialisasi dan bermasyarakat, dan media adalah alat yang digunakan untuk menyampaikan informasi-informasi yang dibutuhkan oleh masyarakat. Hal ini kemudian 
menjadi urgensi dalam penelitian. Namun dalam berkomunikasi, terutama dalam menyampaikan informasi melalui media, di mana media dapat dengan mudah membentuk cara pandang masyarakat, banyak hal-hal yang harus dipertimbangkan kembali berkaitan dengan etika. Sedangkan masyarakat zaman sekarang sudah terbiasa untuk menyaksikan kejadian-kejadian ekstrem yang disajikan melalui media, sehingga kepekaan mereka akan pelanggaran etika yang dilakukan dalam dunia komunikasi melalui media pun sering tak mereka sadari, bahkan hanya diterima mentah-mentah sebagai sebuah informasi semata.

Tabel 1 Pelanggaran UU UTE pada Media Sosial dalam Etika Komunikasi Massa

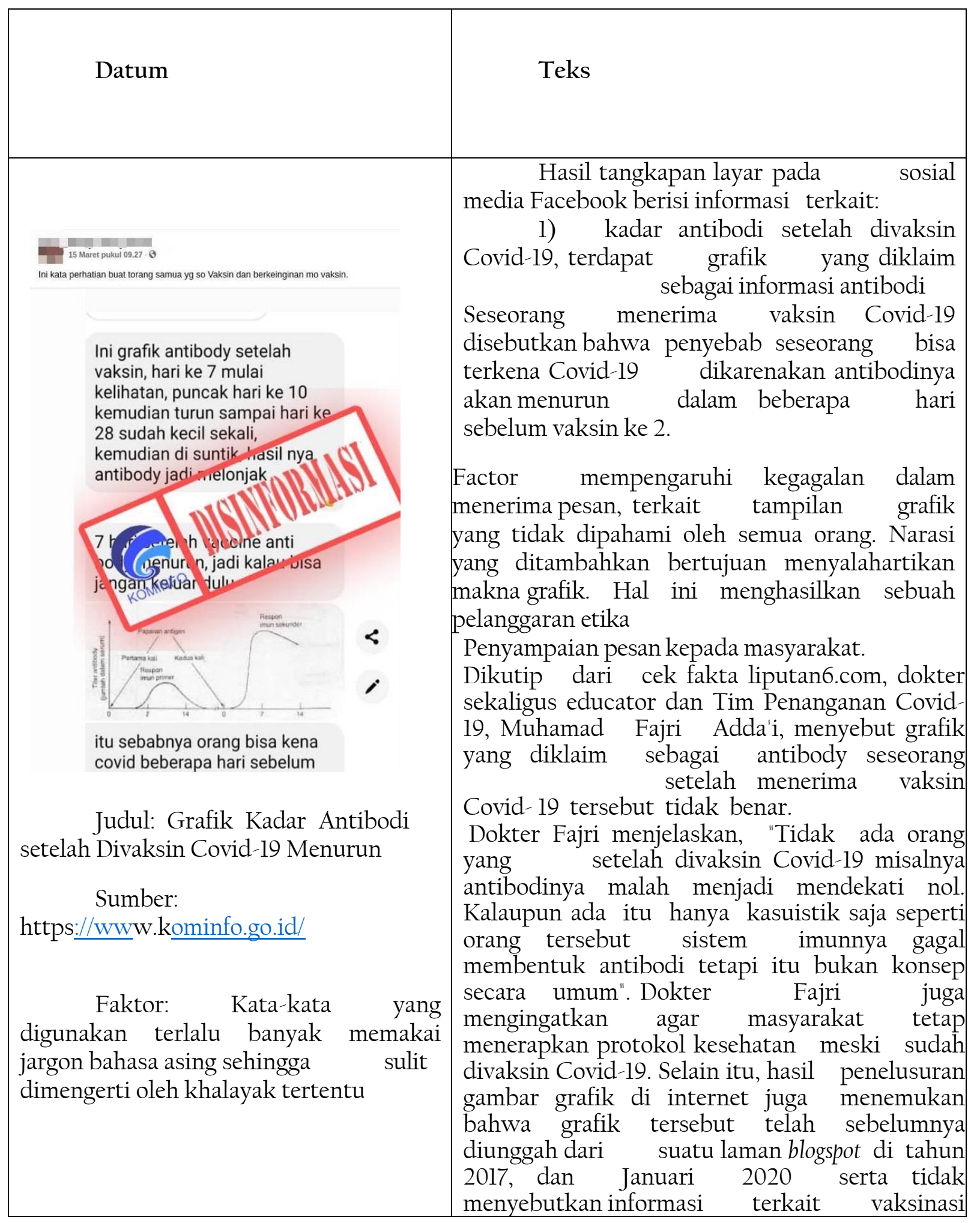


Covid-19. 


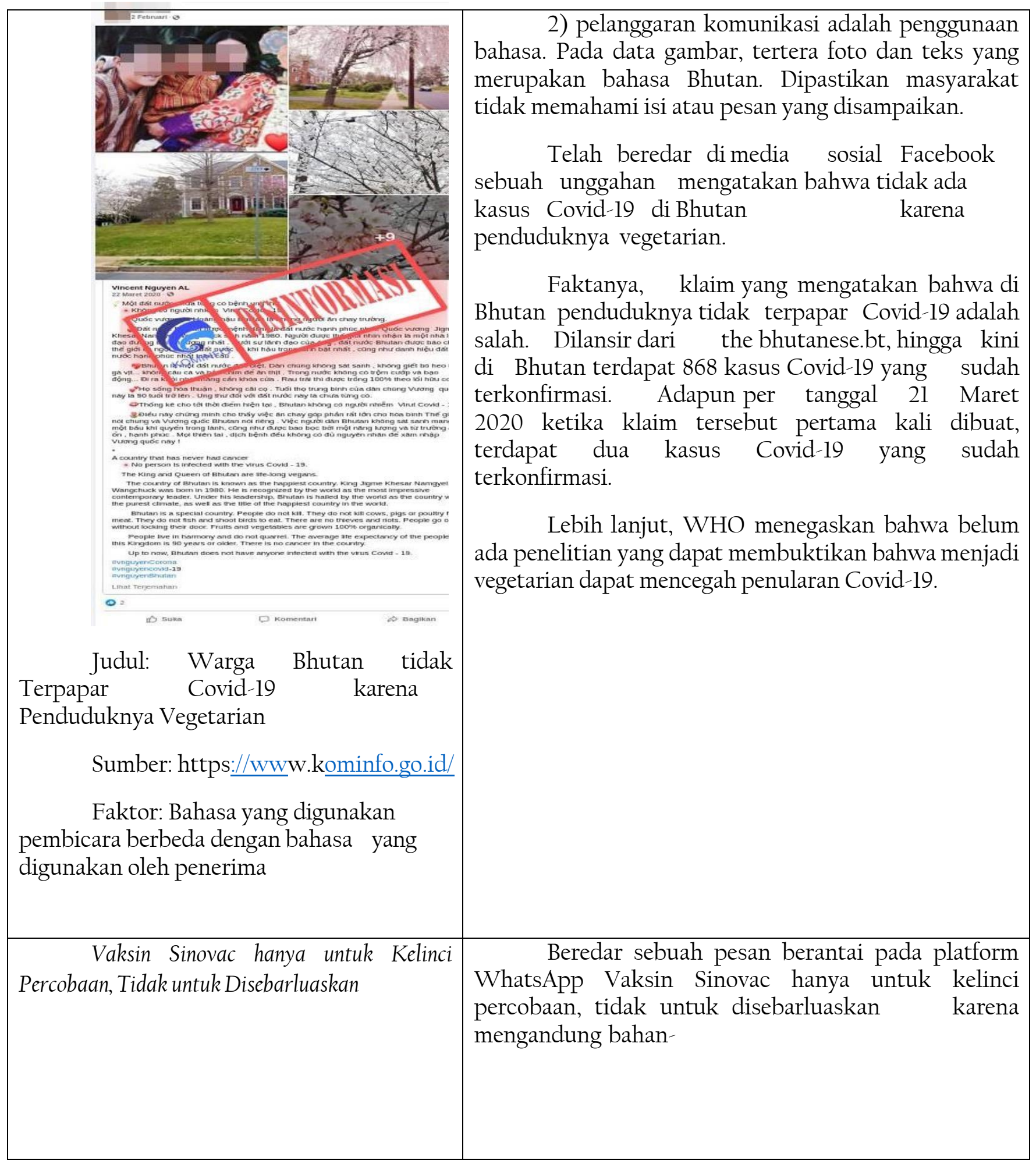




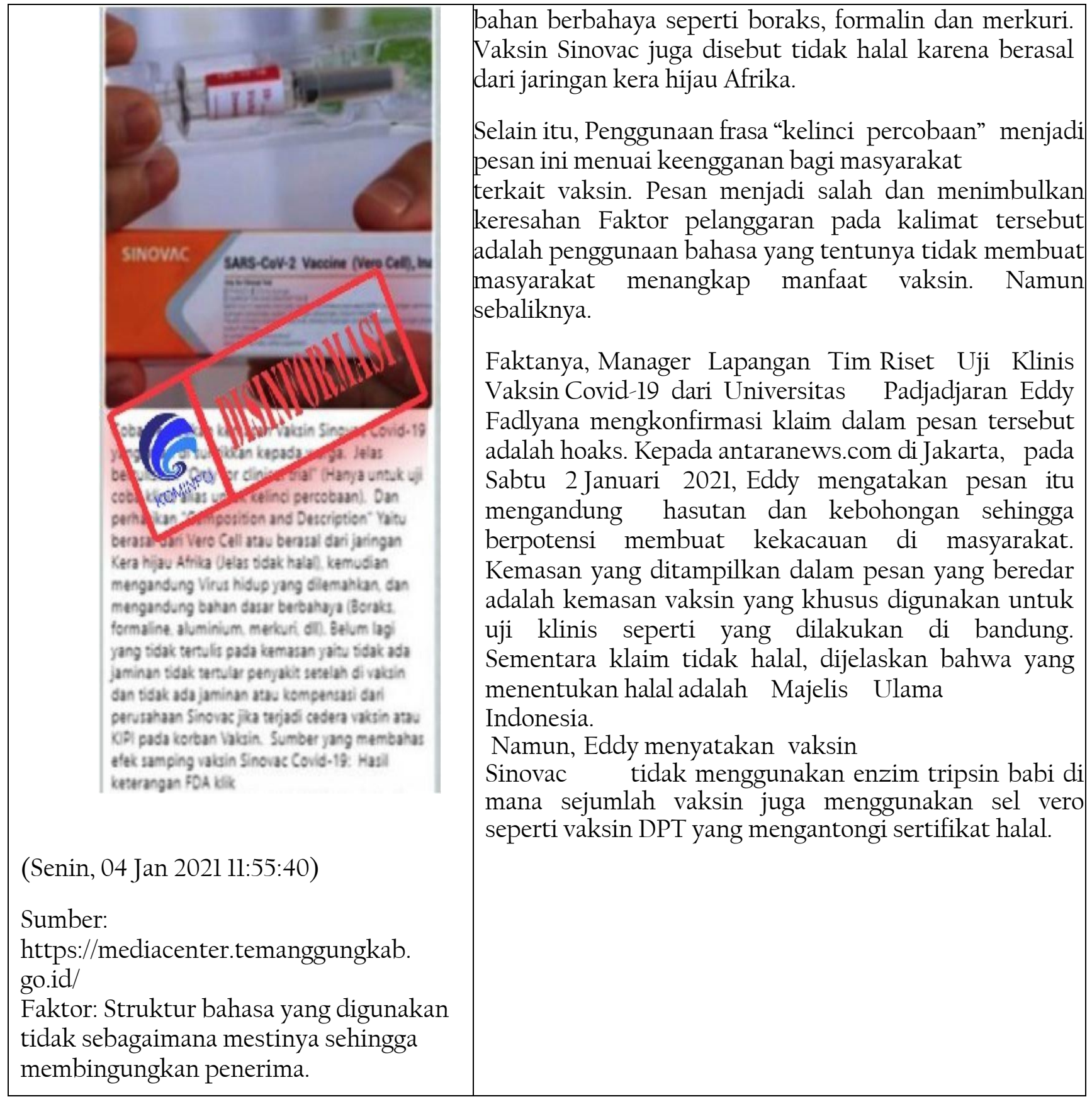




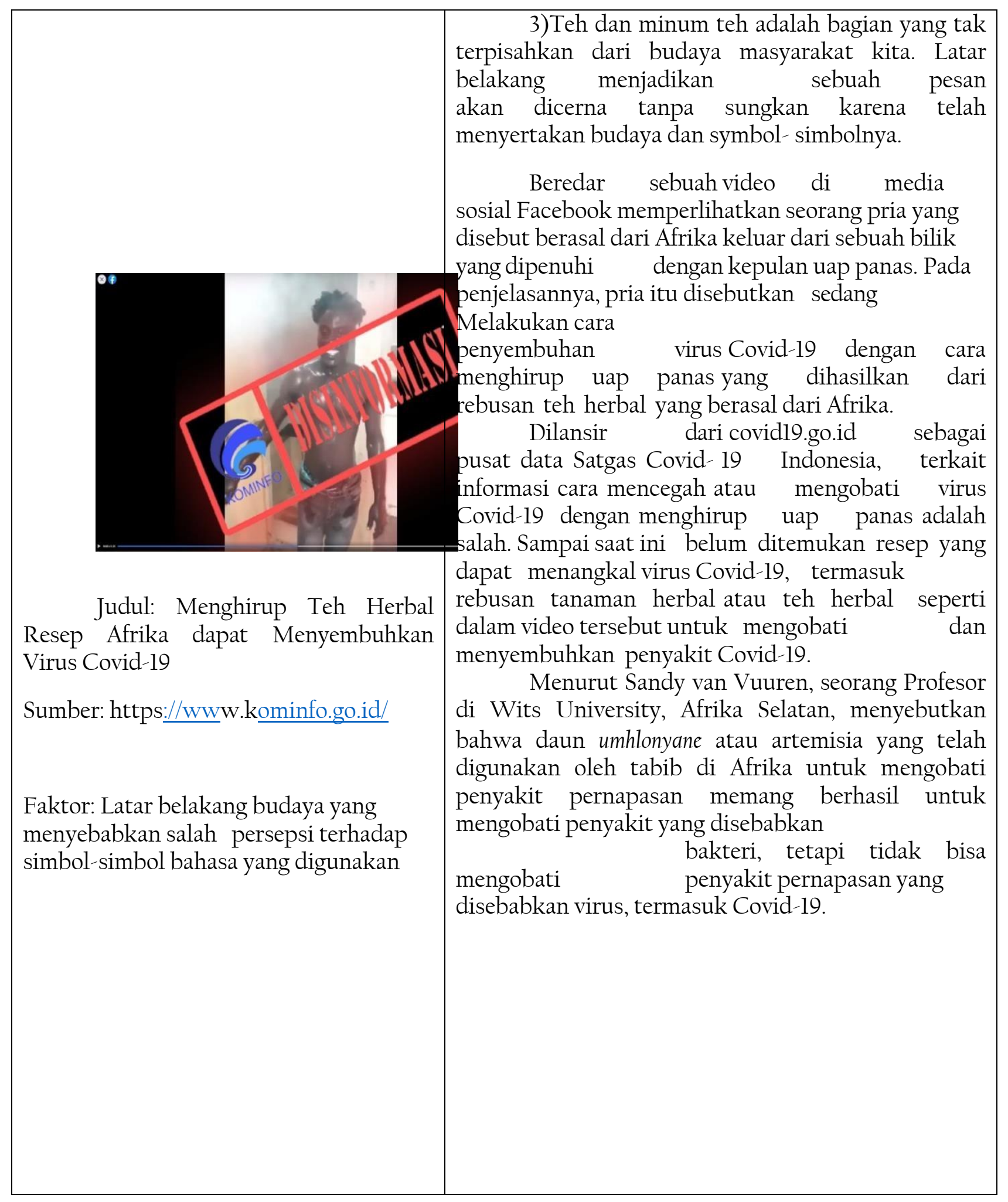




\section{Penegakan Hukum Terhadap Pelanggaran Etika Komunikasi Massa Dalam Media Sosial Menurut UU ITE}

Di dalam Undang-Undang No. 11 tahun 2008 Tentang Informasi dan Elektronik pasal 28 yang berbunyi:

a) Setiap orang dengan sengaja dan tanpa hak menyebarkan berita bohong dan menyesatkan yang mengakibatkan kerugian konsumen dalam Transaksi Elektronik.

b) Setiap orang dengan sengaja dan tanpa hak menyebarkan informasi yang ditujukan untuk menimbulkan rasa kebencian atau permusuhan individu dan/atau kelompok masyarakat tertentu berdasarkan atas suku, agama, ras, dan antar golongan (SARA).

Ada dua bentuk perbuatan pidana ITE dalam pasal 28, masing-masing dirumuskan dalam ayat (1) dan ayat (2).Perbuatan pidana ITE dalam ayat (1) terdiri dari unsur sebagai berikut:

a) Kesalahan : dengan sengaja

b) Melawan hukum : tanpa hak

c) Perbuatan : menyebarkan

d) Objek : berita bohong dan menyesatkan. Akibat konstitusi : mengakibatkan kerugian konsumen dalam transaksi elektronik. Yang mengakibatkan kerugian konsumen dalam transaksi elektronik adalah semua bentuk kerugian, tidak saja kerugian yang dapat dinilai uang, tetapi segala bentuk kerugian. Misalnya, timbulnya perasaan cemas, malu, kesusahan, hilangnya harapan mendapatkan kesenangan atau keuntungan sebagainya (Berlian, 2017).

Unsur-unsur perbuatan pidana dalam ayat (2) adalah sebagai berikut:

a) Kesalahan : dengan sengaja;

b) Melawan hukum : tanpa hak;

c) Perbuatan : menyebarkan;

d) Objek : informasi;

e) Tujuan : untuk menimbulkan rasa kebencian atau permusuhan individu dan/atau kelompok masyarakat tertentu berdasarkan atas suku, agama, ras, dan antar golongan (SARA). (Chazawi\&Ferdian, 2015).

Jadi dari unsur-unsur tersebut seseorang dapat dimintai pertanggungjawaban pidana yang diatur di dalam Undang-Udang No. 11 Tahun 2008 tentang Informasi dan Transaksi Elektronik juncto Undang-Undang No. 19 Tahun 2016 tentang Perubahan atas Undang-Undang No. 11 Tahun 2008 tentang Informasi dan Transaksi Elektronik Pasal 45A ayat (1) dan ayat (2) sebagai berikut :

a) Setiap orang yang dengan sengaja dan tanpa hak menyebarkan berita bohong dan menyesatkan yang mengakibatkan kerugian konsumen dalam Transaksi Elektronik sebagaimana dimaksud dalam Pasal 28 ayat (1) dipidana dengan pidana penjara paling lama 6 (enam) tahun dan/atau denda paling banyak Rp 1.000.000.000,00 (satu miliar rupiah);

b) Setiap orang dengan sengaja dan tanpa hak menyebarkan informasi yang ditujukan untuk menimbulkan rasa kebencian atau permusuhan individu dan/atau kelompok masyarakat tertentu berdasarkan atas suku, agama, ras, dan antar golongan (SARA) sebagaimana 
dimaksud dalam Pasal 28 ayat (2) dipidana dengan pidana penjara paling lama 6 (enam) tahun dan/atau denda paling banyak Rp 1.000.000.000.00, (satu miliar rupiah).

Selain ancaman pidana, pemerintah juga memberikan layanan untuk masyarakat dalam mencari informasi atas kejahatan di media masa atau hoax. Kemenkominfo telah menyediakan sarana pengaduan bagi masyarakat yang merasa dicemarkan nama baiknya melalui media masa, melalui situs https://dumas.kominfo.go.id/. Upaya yang pemerintah lakukan dalam menangkal informasi hoax yang beredar ke masyarakat, informasinya dapat diakses melalui situs online.(Nashihuddin, 2017)

Penegakan hukum terlihat jelas dalam UU Nomor 19 Tahun 2016 tentang Informasi dan Transaksi Elektronik memiliki wewenang yang kuat untuk mengatur publik terkait etika pratik komunikasi ketika di media sosial. Selain Undang-undang, pihak kepolisian juga ambil alih untuk menertibkan masyarakatnya di dunia maya dengan program polisi virtual. Direktorat Tindak Pidana Siber Bareskrim Polri mulai mengaktifkan polisi virtual pada Rabu 24 Februari 2021 untuk mengawasi aktivitas warganet di jejaring dunia maya. Polisi virtual adalah kegiatan pelacakan unggahan tulisan atau gambar yang berpotensi melakukan pelanggaran pidana. Fungsi polisi virtual adalah menegur masyarakat yang mengunggah aktivitas yang berpotensi melanggar UU ITE serta memberi edukasi kepada masyarakat terkait UU ITE (sari n.d.)

Tabel 2 Pelanggaran UU ITE dan Etika Komunikasi Massa

\begin{tabular}{|c|c|c|}
\hline Temuan & Etika Komunikasi Massa & UU ITE \\
\hline $\begin{array}{l}\text { Indikasi } \\
\text { 1. Terlalu banyak memakai } \\
\text { jargon bahasa asing }\end{array}$ & $\begin{array}{l}\text { Susunan kata hendaknya } \\
\text { memperhatikan unsur- } \\
\text { unsur kejelasan, } \\
\text { kelengkapan, dan mudah } \\
\text { dipahami oleh } \\
\text { khalayaknya. } \\
\text { menggunakan jargon asing } \\
\text { dan wajib memberikan } \\
\text { penjelasan jikapun jargon } \\
\text { tetap digunakan dalam } \\
\text { pesan. }\end{array}$ & $\begin{array}{l}\text { Ancaman pidana pelanggaran Pasal } 28 \text { ayat } \\
\text { (1) diatur dalam Pasal 45A ayat (1)" Setiap } \\
\text { Orang yang dengan sengaja dan tanpa hak } \\
\text { menyebarkan berita bohong dan } \\
\text { menyesatkan yang mengakibatkan kerugian } \\
\text { konsumen dalam Transaksi Elektronik } \\
\text { sebagaimana dimaksud dalam Pasal } 28 \text { ayat } \\
\text { (1) dipidana dengan pidana penjara paling } \\
\text { lama } 6 \text { (enam) tahun dan/atau denda paling } \\
\text { banyak Rpl.000.000.000,00 (satu miliar } \\
\text { rupiah)." }\end{array}$ \\
\hline
\end{tabular}

Struktur bahasa dan bahasa yang digunakan harus sesuai dengan masyarakat sebagai bagian dari system komunikasi yang dibangun. jika terdapat perbedaan, maka wajib melakukan penyesuaian dan pemilihan bahasa yang sepadan dengan struktur yang sesuai kaidah.
Ancaman pidana pelanggaran Pasal 28 ayat (2) diatur dalam Pasal 45A ayat (2) "Setiap Orang dengan sengaja dan tanpa hak menyebarkan informasi yang ditujukan untuk menimbulkan rasa kebencian atau permusuhan individu dan/atau kelompok masyarakat tertentu berdasarkan atas suku, agama, ras, dan antargolongan (SARA) sebagaimana dimaksud dalam Pasal 28 ayat (2) dipidana dengan pidana penjara paling lama 6 (enam) tahun dan/ atau denda paling banyak Rp 1.000.000. 000,00 (satu miliar rupiah)." 
3. Latar belakang budaya

$$
\text { yang }
$$
menyebabkan salah persepsi
Menghindari terjadinya salah persepsi terkait perbedaan budaya antara materi komunikasi massa. Pesan yang diambil dan disampaikan dari latar budaya berbeda wajib memberikan catatan dan klarifikasi sumber asal, agar penerima pesan yang mencerna melalui media massa memahami konteks budaya asal pesan tersebut dating, yaitu saring dan sharing.
Ancaman pidana pelanggaran Pasal 28 ayat (1) diatur dalam Pasal 45A ayat (1) "Setiap Orang yang dengan sengaja dan tanpa hak menyebarkan berita bohong dan menyesatkan yang mengakibatkan kerugian konsumen dalam Transaksi Elektronik sebagaimana dimaksud dalam Pasal 28 ayat (1) dipidana dengan pidana penjara paling lama 6 (enam) tahun dan/atau denda paling banyak Rpl.000.000.000,00 (satu miliar rupiah)."

Berdasarkan hasil temuan dari penelitian ini terlihat jelas adanya pelanggaran etika komunikasi dalam media sosial selama pandemi. Diantaranya, ditemukan:

1) Beredarnya informasi di media sosial FB dengan judul "Grafik Kadar Antibodi setelah Divaksin Covid-19 Menurun" adanya penggunaan jargon menggunakan bahasa asing sehingga sulit dimengerti khalayak umum dan ditambahkan grafik yang tidak semua orang memahami dengan tujuan untuk menyalahartikan maknanya. Gambar grafik yang digunakan ternyata sudah pernah diunggah beberapa tahun sebelumnya di suatu laman serta tidak terkait vaksinasi Covid-19.

2) Beredarnya pesan berantai pada platform WhatsApp dengan judul "Vaksin Sinovac hanya untuk Kelinci Percobaan Tidak untuk Disebarluaskan" terlihat adanya struktur kalimat yang digunakan tidak sebagaimana mestinya sehingga mengandung hasutan dan kebohongan dapat berpotensi menimbulkan kekacauan di masyarakat. Penegakan hukum terlihat jelas diatur dalam UU Nomor 19 Tahun 2016 tentang Informasi dan Transaksi Elektronik memiliki wewenang yang kuat untuk mengatur publik terkait etika praktik komunikasi ketika di media sosial. Selain Undang-undang, pihak kepolisian juga ambil alih untuk menertibkan masyarakatnya di dunia maya dengan program polisi virtual.

3) Beredarnya video di FB dengan judul "Menghirup Teh Herbal Resep Afrika dapat Menyembuhkan Virus Covid-19” adanya pelanggaran etika komunikasi dengan latar belakang budaya menyebabkan salah persepsi padahal sampai saat ini belum ada resep yang dapat menangkal Covid-19 termasuk rebusan teh herbal. Kedua temuan tersebut pelakunya bisa terkena ancaman pidana pelanggaran Pasal 28 ayat (1) diatur dalam Pasal 45A ayat (1). Selain kedua temuan tersebut masih ada temuan yang pelakunya bisa dijerat Ancaman pidana pelanggaran Pasal 28 ayat (2) diatur dalam Pasal 45A ayat (2)

Mulawarman dan Aldiladias, 2017 mengungkapkan dalam bulletin Psikologi menemukan perilaku pengguna media sosial swafoto, belanja during, cyberwar, personalisasi diri pengguna dan budaya share (Mulawarman \& Nurfitri, n.d.). 


\section{SIMPULAN}

Sosialisasi UU ITE terus dijalankan dan belajar mengenal indikasi pelanggarannya. Ditemukan tiga pelanggaran UU ITE pasal 28: 1)tampilan grafik dan penyalahgunaan makna grafik, 2) struktur Bahasa membingungkan, dan 3) salah persepsi karena latarbelakang budaya.

\section{SARAN}

Dalam menulis di media massa baik old media maupun new media, diharapkan pengguna berhati-hati dalam memilih kata-kata, Menyusun kata-kata tersebut agar pembaca tidak salah tafsir atau maknanya menjadi ganda. Dalam memahami kata-kata sebaiknya melihat konteks, waktu dan tempatnya. Untuk penelitian yang akan datang sebaiknya melihat persoalan etika komunikasi massa menurut islam dan etika-etika yang masih jarang di bahas pada jurnal lainnya.

\section{DAFTAR PUSTAKA}

Cangara, H. (2006). Pengantar Ilmu Komunikasi. Raja Grafindo Persada, Jakarta.

Evans, D., \& Bratton, S. (2012). Social Media Marketing: An Hour a Day. Wiley Publishing, Inc.

Junaedi, F. (2019). Etika Komunikasi di Era Siber: Teori dan Praktik. Rajawali Pers.

Mulawarman, \& Nurfitri, A. D. (n.d.). Perilaku Pengguna Media Sosial beserta Implikasinya Ditinjau dari Perspektif Psikologi Sosial Terapan. 2017, Vol. 25 No. 1, 36-44.

Nashihuddin, W. (2017). Pustakawan, Penangkal Informasi Hoax Di Masyarakat. Yuma Pustaka.

Sugiarso, B. A., Lumenta, A. S. M., \& Mamahit, D. J. (2017). INTERNET CERDAS DAN JERAT

UNDANG-UNDANG INFORMASI DAN TRANSAKSI ELEKTRONIK (UU ITE). Jurnal Teknik Elektro Dan Komputer, Vol. 6 No. 3, 117-122.

sari. n.d. Polemik UU ITE Dan Polisi Virtual Dalam Mengatur Etika Praktik Komunikasi Di Media Sosial.

(Undang-Undang Nomor 11 Tahun 2008 Tentang Informasi Dan Transaksi Elektronik, n.d.)

(Undang-Undang Nomor 12 Tahun 2011 Tentang Pembentukan Peraturan Perundang-Undangan, n.d.)

(Undang-Undang Nomor 19 Tahun 2016 Tentang Perubahan Atas Undang-Undang Nomor 11 Tahun 2008 Tentang Informasi Dan Transaksi Elektronik, n.d.) 